\title{
Ovarian morphology and the concentration of steroids during the oestrous cycle of sheep actively immunized against androstenedione
}

\author{
R. J. Scaramuzzi, D. T. Baird, I. J. Clarke*, N. D. Martensz $\dagger$ and \\ P. F. A. Van Look $\ddagger$ \\ C.S.I.R.O., Division of Animal Production, \\ P.O. Box 239, Blacktown, New South Wales 2148, Australia, \\ and \\ M.R.C. Unit of Reproductive Biology, \\ 2 Forrest Road, Edinburgh EH1 2QW, U.K.
}

\begin{abstract}
Summary. Ewes were immunized against androstenedione-11 $\alpha$-hemisuccinyl-bovine serum albumin (androstenedione-11-BSA) or BSA alone (controls). The ovaries were examined macroscopically and ovarian venous blood was collected at laparotomy by in-situ cannulation of the ovarian vein on Day 10 of the oestrous cycle, or by needle puncture of the ovarian vein $36 \mathrm{~h}$ after prostaglandin treatment. Follicular fluid was also collected from follicles $>5 \mathrm{~mm}$ diameter in some ewes. Ovaries and adrenal glands were collected and examined histologically. Oestrone, oestradiol-17 $\beta$, androstenedione, testosterone and progesterone were measured by radioimmunoassays. Immunization against androstenedione-11-BSA was followed by an increase in the number of surface follicles $>3 \mathrm{~mm}$ in diameter and in ovulation rate. These changes were accompanied by an increased production of androgens (especially androstenedione) and of oestrogens during the preovulatory period. There were no observed changes in the adrenal cortex or pituitary glands, but the ovaries were heavier in immunized ewes and luteinized follicles were present in the ovaries of 1 of 4 immunized ewes.

These results show that immunization against androstenedione-11-BSA leads to increased ovulation rate and suggest two possible mechanisms: (1) interference with the negative feedback effects of oestradiol- $17 \beta$ and/or (2) a reduction in the incidence of follicular atresia.
\end{abstract}

\section{Introduction}

The ovaries of the ewe secrete at least 9 steroids (Baird, 1978), including androgens such as androstenedione and testosterone. Little is known of the physiological functions of these circulating androgens. Sheep immunized against androstenedione show increases in ovulation rate (Scaramuzzi, Davidson \& Van Look, 1977; Van Look, Clarke, Davidson \& Scaramuzzi, 1978) and in the levels of LH and progesterone in jugular venous plasma and a decrease in the levels of FSH (Martensz \& Scaramuzzi, 1979). These studies show that immunization against androstenedione produces large changes in the hypothalamic-pituitary-ovarian feedback and imply that

* Present address: Reproduction Research Section, Department of Physiology, University of Melbourne, Werribee, 3030, Victoria, Australia.

† Present address: Department of Anatomy, Cambridge University, 20 Downing Street, Cambridge, CB3 2DY, U.K.

$\ddagger$ Present address: Vrouwenkliniek, Academisch Ziekenhuis Leiden, Rijnsburgerweg 10, Leiden, The Netherlands. 
androstenedione is an active regulator of ovarian feedback at the hypothalamus and pituitary gland.

One of the principal functions of feedback between the hypothalamus, pituitary gland and ovaries is to ensure the regular occurrence of ovulation. Changes in these feedback systems (no matter how large) are of little biological consequence if ovulation is unaffected. Immunization against androgens (Martensz, 1977; Scaramuzzi et al., 1977; Martensz \& Scaramuzzi, 1979) can interfere with ovarian function and alter the ovulation rate of sheep. The present study investigates changes, in sheep actively immunized against androstenedione, in ovarian morphology and the concentration of steroids in ovarian venous blood and follicular fluid, particularly in relation to the resulting alterations in ovulation rate.

\section{Materials and Methods}

\section{Immunization procedures}

During October 19725 Welsh Mountain ewes were immunized with $2 \cdot 1 \mathrm{mg}$ androstenedione-1 $1 \alpha$-hemisuccinyl-bovine serum albumin (androstenedione-11-BSA) in Freund's complete adjuvant (Scaramuzzi, Corker, Young \& Baird, 1975). The animals were given booster immunizations in March 1973 (2.0 mg), June 1974 (2.0 mg), November 1974 (2.0 mg) and July $1975(0.6 \mathrm{mg})$. A control group of 5 ewes was immunized against bovine serum albumin (BSA) at the same times.

A second group of 25 Welsh Mountain ewes was immunized against androstenedione-11BSA (18 ewes) or BSA ( 7 ewes) in August $1975(1.3 \mathrm{mg}$ ) and given booster immunizations in November $1975(1.0 \mathrm{mg})$ and October $1976(1.0 \mathrm{mg})$.

\section{Group 1: cannulation of ovarian vein and collection of tissues}

During September 1975 oestrus and ovulation were synchronized in the first group of ewes (because of deaths now reduced to 4 immunized and 4 control ewes) using intravaginal progestagen pessaries (Synchromate: G.D. Searle \& Co., High Wycombe, Bucks). Following removal of the pessaries, all ewes commenced regular oestrous cycles of 16-19 days duration (oestrus = Day 0). Cannulation of both ovarian veins was carried out on Day 10 (range 8-11) of the third oestrous cycle following synchronization of oestrus. Anaesthesia was induced with sodium thiopentone and maintained by halothane. The ovaries were exposed through a midventral incision and the surface morphology was recorded. The ovarian veins were successfully cannulated (Baird \& Scaramuzzi, 1976) in 7/8 ewes and a $25 \mathrm{ml}$ sample of ovarian venous blood was collected. A sample of jugular venous blood was collected by needle puncture midway through the collection of the ovarian venous blood sample. The ewe was then killed and the ovaries and adrenals removed, and processed for histology. The pituitary gland was also removed, dissected free of connective tissue and weighed.

\section{Group 2: collection of ovarian venous blood}

Oestrus and ovulation were synchronized in the second group of ewes (because of deaths now reduced to 16 immunized and 7 control ewes) in September 1976, using intravaginal pessaries as described above. Regular oestrous cycles occurred following removal of the pessaries. Premature luteal regression was induced by intramuscular injection of $100 \mu \mathrm{g}$ of a prostaglandin F analogue (Cloprostenol: ICI Ltd, Macclesfield, Cheshire) between Days 8 and 12 of the second oestrous cycle after synchronization. Laparotomies, as described above, were then performed $36 \mathrm{~h}$ (range 33-44 h) after injection of Cloprostenol, and a $10 \mathrm{ml}$ sample of ovarian venous blood was collected by aspiration in 22 of the ewes (Scaramuzzi \& Land, 1978). A $20 \mathrm{ml}$ 
sample of jugular venous blood was collected at the same time. Following collection of blood samples follicular fluid was aspirated into a $1 \mathrm{ml}$ syringe, using a 23-gauge needle, from all visible follicles of $>5 \mathrm{~mm}$ diameter.

\section{Histology}

Corpora lutea were dissected free from the ovaries. The corpora lutea and the remainder of the ovaries were weighed separately and placed in aqueous Bouin's fixative. The adrenal glands were trimmed, weighed and placed in Helly's fixative. After 24-36 h fixation the tissues were removed from the fixatives, the adrenals washed overnight in running water, and stored in $70 \%$ $\mathrm{v} / \mathrm{v}$ ethanol. The tissues were embedded in paraffin wax, and sectioned at $15 \mu \mathrm{m}$. Representative sections were stained with haematoxylin and eosin and examined under the light microscope.

\section{Assay procedures}

The blood samples from both experiments were collected in heparinized tubes and the plasma was removed after centrifugation at $4^{\circ} \mathrm{C}$ and stored at $-20^{\circ} \mathrm{C}$ until assay. Follicular fluid was also stored at $-20^{\circ} \mathrm{C}$. Following acidification with $1 \mathrm{~N}$-hydrochloric acid, the concentrations of steroids in plasma were measured using radioimmunoassays described in detail in other publications from this laboratory: oestrone, oestradiol- $17 \beta$ and androstenedione (Baird, Burger, Heavon-Jones \& Scaramuzzi, 1974; Baird, Swanston \& Scaramuzzi, 1976); testosterone (Corker \& Davidson, 1978); and progesterone (Scaramuzzi et al., 1975). For the assay of these steroids in follicular fluid the same antisera, as indicated above, were used but the methods of extraction and separation were as described from this laboratory for follicular fluid (McNatty et al., 1976) and luteal tissue (Swanston, McNatty \& Baird, 1977). The characteristics of these assays used in the present analyses are listed in Table 1.

Table 1. Details of the assays used

\begin{tabular}{lccc}
\hline & Antiserum & $\begin{array}{c}\text { Inter-assay } \\
\text { precision }(\%)\end{array}$ & $\begin{array}{c}\text { Limit of } \\
\text { sensitivity (pg/ml) }\end{array}$ \\
\hline Oestrone & $029-14$ & 12 & 10 \\
Oestradiol-17 $\beta$ & $-*$ & $6 \cdot 1-9 \cdot 5$ & 10 \\
Androstenedione & Shopman & 15 & 150 \\
Testosterone & E 01 & 11.5 & 10 \\
Progesterone & $91920 / 9$ & 13 & 200 \\
\hline
\end{tabular}

* The antiserum used for the assay of the oestradiol fraction was a specific one raised against 17ß-oestradiol-6(O-carboxymethyl)-oxine-BSA (Dean, Exley \& Johnson, 1971; Van Look, Hunter, Corker \& Baird, 1977).

The binding of exogenous tritiated steroids by jugular venous plasma from the control and immunized ewes was determined by dextran-charcoal radioassay (Scaramuzzi et al., 1975) and by equilibrium dialysis against physiological saline $(9 \mathrm{~g} \mathrm{NaCl} / 1)$ (Rivarola, Forest \& Migeon, 1968).

\section{Statistical procedures}

The concentrations of steroids in ovarian venous plasma and follicular fluid were analysed using a split-plot analysis of variance and a 2-way non-orthogonal analysis of variance respectively. Before the analyses all steroid concentrations were transformed to logarithms to overcome heterogeneity of variance. Data on ovulation rates were analysed by Fisher's exact 
test, follicle numbers by Wilcoxon's Rank sum test and diameter of follicles by a one-way analysis of variance. All other data were analysed using the $t$ test.

\section{Group 1}

\section{Results}

The data in Table 2 show that the ovaries of ewes immunized against androstenedione-11BSA were heavier than those from control ewes. The increase in ovarian weight resulted from both an increased number of corpora lutea and an increase in the weight of non-luteal ovarian tissue. The numbers of corpora lutea and of visible surface follicles $>3 \mathrm{~mm}$ in diameter were higher in the immunized ewes than in the controls. The weights of the corpora lutea, adrenal and pituitary glands were not significantly affected (Table 2).

Table 2. The ovulation rate, number of surface follicles $>3 \mathrm{~mm}$, and the weight of ovaries, corpora lutea, adrenal glands and pituitary glands on Day 10 of the oestrous cycle of sheep actively immunized against androstenedione-11-BSA (immunized ewes) or BSA (control ewes)

\begin{tabular}{|c|c|c|}
\hline & $\begin{array}{l}\text { Immunized ewes } \\
\qquad(\mathrm{N}=4)\end{array}$ & $\begin{array}{l}\text { Control ewes } \\
\quad(\mathrm{N}=4)\end{array}$ \\
\hline Wt of ovaries including $\mathrm{CL}(\mathrm{g})$ & $2 \cdot 26 \pm 0 \cdot 24^{* *}$ & $1 \cdot 19 \pm 0.18$ \\
\hline No. of CL (ovulation rate) & $2.00 \pm 0.00$ & $1.50 \pm 0.25$ \\
\hline Wt of CL $(\mathrm{g})$ & $0.61 \pm 0.04$ & $0.50 \pm 0.05$ \\
\hline No. of visible surface follicles per ewe ( $>3 \mathrm{~mm}$ diam.) & $3.0 \pm 0.3^{*}$ & $1.0 \pm 0.3$ \\
\hline Wt of adrenal glands $(\mathrm{g})$ & $1.93 \pm 0.07$ & $1.71 \pm 0.09$ \\
\hline Wt of pituitary glands (mg) & $515 \pm 28$ & $667 \pm 75$ \\
\hline
\end{tabular}

Values are mean \pm s.e.m.

Significantly different from control values: ${ }^{*} P<0.05,{ }^{* *} P<0.01$.

Steroid concentrations in jugular venous and ovarian venous plasma are presented in Table 3. The concentrations of androstenedione and testosterone were significantly elevated in the immunized ewes, but those of progesterone and oestrone were significantly elevated only in jugular venous plasma. Oestradiol concentrations were unchanged.

Histological examination of the adrenal glands showed no obvious hypertrophic or hyperplastic changes of the steroid-secreting cells of the adrenal cortex. Likewise, examination of the ovaries did not show any obvious changes in 3 of the ewes immunized against androstenedione11-BSA (Plate 1). The other similarly immunized ewe showed luteinization of the membrana granulosa in two large follicles but exhibited regular oestrous cycles up to the end of the observations.

\section{Group 2}

The results are shown in Tables 4 and 5 and in general they are consistent with the results of Group 1. The ovulation rate and the number of visible surface follicles $>3 \mathrm{~mm}$ in diameter were significantly increased in immunized ewes. The size distribution of these follicles was also altered so that there were relatively more larger follicles in immunized ewes. The numbers of small visible

\section{PLATE 1}

Figs 1-4. Graafian follicle (Figs 1 and 2) and corpus luteum (Figs 3 and 4) of a control ewe (immunized against BSA). Figs 1 and 3, $\times 132$; Figs 2 and $4, \times 336$.

Figs 5-8. Graafian follicle (Figs 5 and 6) and corpus luteum (Figs 7 and 8 ) of normal appearance in a ewe immunized against androstenedione-11-BSA. Compare with Figs 1-4. Figs 5 and $7, \times 132$; Figs 6 and $8, \times 336$. 
PLATE 1
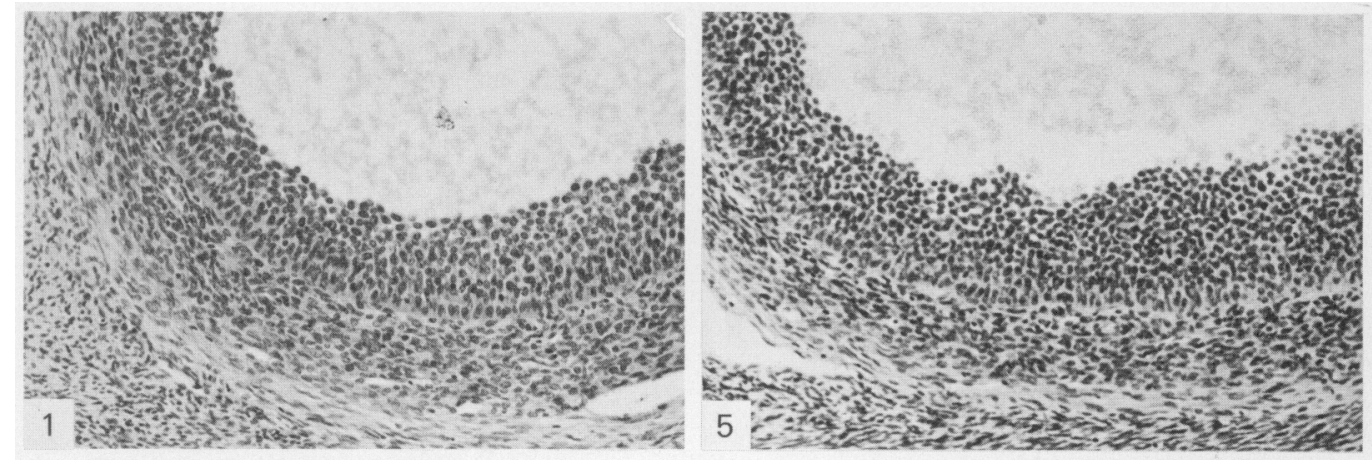

'? Y."
1) owp.

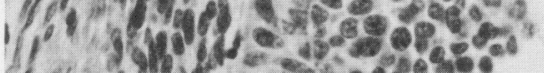

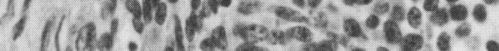

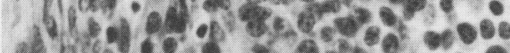
Af hig

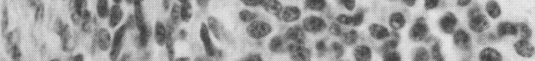

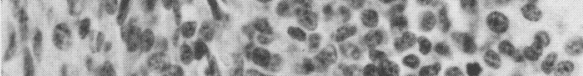

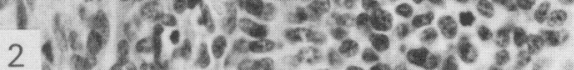

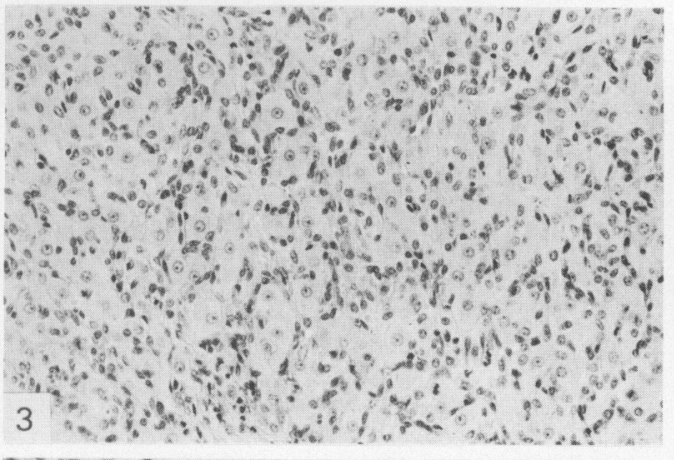

3. (5.

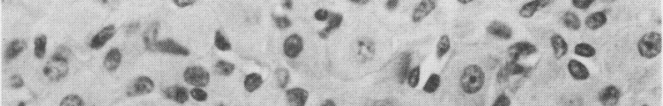

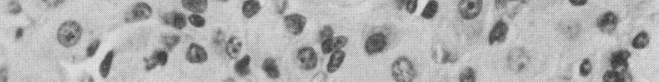

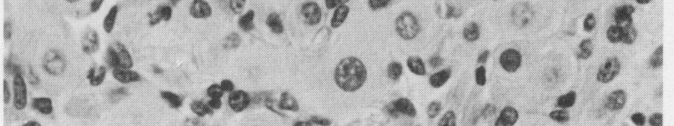

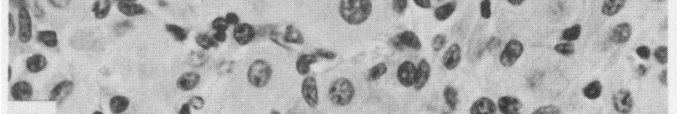

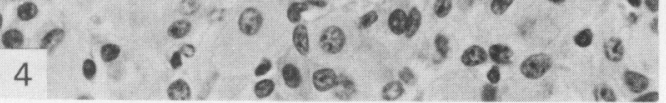

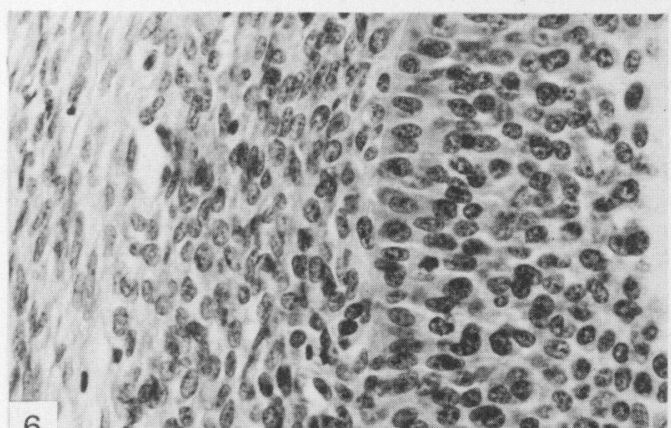

6 is ${ }^{3}$ a

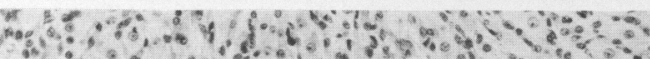

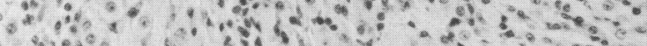

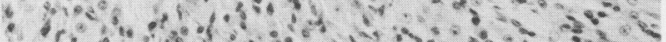

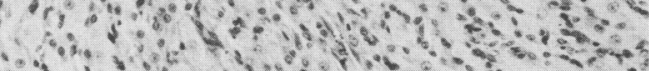

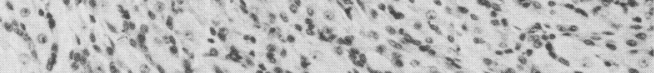

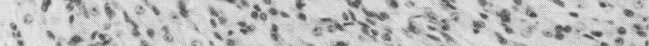

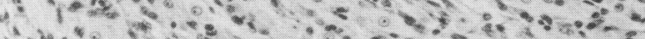

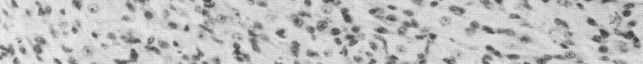

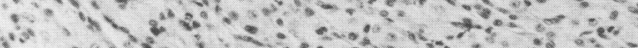

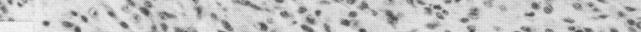

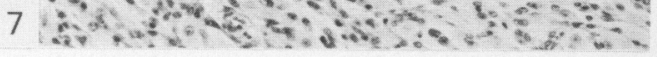

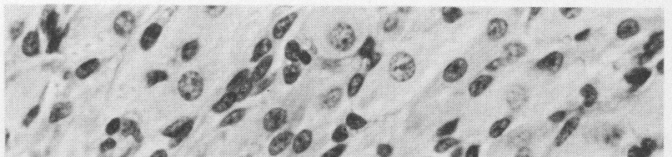

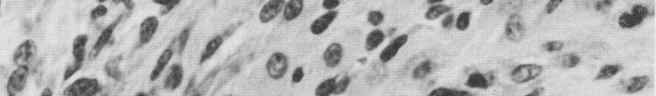

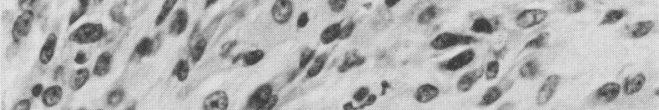

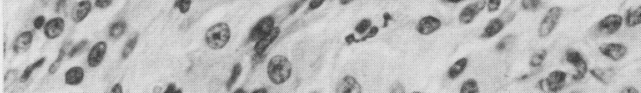
8 (a) a 
Table 3. The concentration of steroids in ovarian venous and jugular venous plasma on Day 10 of the oestrous cycle in sheep actively immunized against androstenedione-11-BSA (immunized ewes) or BSA (control ewes)

\begin{tabular}{llcc}
\hline \multicolumn{1}{c}{ Steroid } & Vein & $\begin{array}{c}\text { Immunized ewes } \\
(\mathbf{N}=4)\end{array}$ & $\begin{array}{c}\text { Control ewes } \\
(\mathbf{N}=3)\end{array}$ \\
\hline Oestrone $(\mathrm{pg} / \mathrm{ml})$ & Ovarian & $109 \pm 11$ & $96 \pm 18$ \\
& Jugular & $31 \pm 4 *$ & $19 \pm 3$ \\
Oestradiol-17ß $(\mathrm{pg} / \mathrm{ml})$ & Ovarian & $62 \pm 22$ & $52 \pm 13$ \\
& Jugular & $29 \pm 3$ & $33 \pm 4$ \\
Androstenedione $(\mathrm{pg} / \mathrm{ml})$ & Ovarian & $12400 \pm 1520^{* * *}$ & $315 \pm 62$ \\
& Jugular & $5025 \pm 1211^{* * *}$ & $125 \pm 72$ \\
Testosterone $(\mathrm{pg} / \mathrm{ml})$ & Ovarian & $385 \pm 55^{*}$ & $188 \pm 54$ \\
& Jugular & $128 \pm 54$ & $44 \pm 15$ \\
Progesterone $(\mathrm{ng} / \mathrm{ml})$ & Ovarian $\dagger$ & $765 \pm 73$ & $582 \pm 138$ \\
& Ovarian & 116,29 & $3 \cdot 9,8 \cdot 1$ \\
& Jugular & $26 \cdot 3 \pm 3 \cdot 3^{* * *}$ & $3 \cdot 1 \pm 0 \cdot 2$ \\
\hline
\end{tabular}

Values are mean \pm s.e.m.

Significantly different from control values: ${ }^{*} P<0.05,{ }^{* * *} P<0.001$ (probabilities apply to log transformed data). + Vein draining ovaries containing corpora lutea.

$\ddagger$ Vein draining ovaries not containing corpora lutea, individual values.

surface follicles $<3 \mathrm{~mm}$ in diameter, however, were not increased. The concentrations of oestradiol-17 $\beta$ and androstenedione in ovarian venous plasma were increased in the immunized ewes but testosterone concentrations were unchanged (Table 4).

Table 4. The effect of active immunization of ewes against androstenedione-11-BSA (immunized ewes) or BSA (control ewes) on ovulation rate, follicular development, and steroid levels in ovarian venous plasma during the periovulatory period

\begin{tabular}{lcc}
\hline & $\begin{array}{c}\text { Immunized ewes } \\
(\mathrm{N}=15)\end{array}$ & $\begin{array}{c}\text { Control ewes } \\
(\mathrm{N}=7)\end{array}$ \\
\hline No. of CL (ovulation rate) & $2 \cdot 3 \pm 0 \cdot 2^{* * *}$ & $1 \cdot 1 \pm 0 \cdot 2$ \\
No. of visible surface follicles per ewe $(>3 \mathrm{~mm}$ diam.) & $5 \cdot 0 \pm 0 \cdot 5^{*}$ & $3 \cdot 1 \pm 0 \cdot 7$ \\
No. of visible surface follicles per ewe $(<3 \mathrm{~mm}$ diam.) & $11 \cdot 3 \pm 2 \cdot 5$ & $11 \cdot 6 \pm 1 \cdot 4$ \\
Time from PG injection to laparotomy $(\mathrm{h})$ & $39 \cdot 55 \pm 1 \cdot 02$ & $38 \cdot 38 \pm 1 \cdot 36$ \\
Oestradiol-17ß conc. $(\mathrm{pg} / \mathrm{ml})$ & $830 \pm 169^{*}$ & $590 \pm 148$ \\
Androstenedione conc. $(\mathrm{pg} / \mathrm{ml})$ & $12105 \pm 1113^{* * *}$ & $1120 \pm 364$ \\
Testosterone conc. $(\mathrm{pg} / \mathrm{ml})$ & $310 \pm 20$ & $336 \pm 54$ \\
\hline
\end{tabular}

Values are mean \pm s.e.m.

Significantly different from control values: ${ }^{*} P<0.05,{ }^{* * *} P<0.001$ (probabilities for the steroid concentrations apply to $\log$ transformed data).

The concentration of steroids in follicular fluid were extremely variable (Table 5). Androstenedione was the only steroid of those measured whose concentration was increased by immunization against androstenedione-11-BSA. Testosterone, although initially very low, was decreased even further by immunization. Follicles were classified as active or inactive depending on whether they contained $>$ or $<50 \mathrm{ng}$ oestradiol $-17 \beta / \mathrm{ml}$ follicular fluid. Progesterone was increased in active follicles of control ewes and in all follicles from the immunized ewes. The concentration of oestradiol-17 $\beta$ in the ovarian vein draining an ovary containing at least one active follicle was significantly greater than that in the ovarian vein draining an ovary containing only inactive follicles (Table 5). The concentration of oestradiol-17 $\beta$ in the ovarian vein was significantly correlated with the concentration of oestradiol-17 $\beta$ in follicular fluid $(r=0.45$; $n=34 ; P<0.01$. 
Table 5. The concentrations of steroids in follicular fluid from active or inactive follicles (see text for definitions) and of oestradiol- $17 \beta$ in ovarian venous plasma during the periovulatory period from sheep immunized against androstenedione-11-BSA (immunized ewes) or BSA (control ewes)

\begin{tabular}{|c|c|c|c|c|c|c|}
\hline \multirow{4}{*}{$\begin{array}{l}\text { Diameter of follicle }(\mathrm{mm}) \\
\text { Oestradiol- } 17 \beta(\mathrm{ng} / \mathrm{ml})\end{array}$} & \multicolumn{4}{|c|}{ Immunized ewes } & \multicolumn{2}{|c|}{ Control ewes } \\
\hline & \multicolumn{2}{|l|}{ Active follicles } & \multicolumn{2}{|l|}{ Inactive follicles } & Active follicles & Inactive follicles \\
\hline & $9.2 \pm 0.4$ & $(17)^{\mathrm{a}}$ & $7.6 \pm 0.3$ & $(18)^{b}$ & $7.6 \pm 0.4(5)^{b}$ & $8.7 \pm 0.7$ \\
\hline & & & & & & \\
\hline Follicular fluid & $136 \cdot 7 \pm 14 \cdot 3$ & $(17)^{a}$ & $24.9 \pm 4.0$ & $(18)^{b}$ & $117.1 \pm 17.9(5)^{\mathrm{a}}$ & $8.4 \pm 5.6(3)^{b}$ \\
\hline Ovarian vein & $1.38 \pm 0.27$ & $(15)^{a}$ & $0.29 \pm 0.05$ & $(11)^{c}$ & $0.91 \pm 0.18(5)^{b}$ & $0.58+0.31(3)^{c}$ \\
\hline Androstenedione $(\mathrm{ng} / \mathrm{ml})$ & $89.3 \pm 27.2$ & $(16)^{2}$ & $106.8 \pm 29.7$ & $(18)^{a}$ & $13.0 \pm 2.6(4)^{b}$ & $9.5,3.7 \quad(2)$ \\
\hline Testosterone $(\mathrm{ng} / \mathrm{ml})$ & $4.0 \pm 0.4$ & $(16)^{a}$ & $4.1 \pm 0.8$ & $(17)^{a}$ & $8.0 \pm 2.7(5)^{b}$ & 8.7 (1) \\
\hline Progesterone $(\mathrm{ng} / \mathrm{ml})$ & $114 \pm 18$ & $(17)^{a}$ & $125 \pm 27$ & $(17)^{a}$ & $78 \pm 13$ & $15 \pm 2 \quad(3)^{c}$ \\
\hline
\end{tabular}

Values are mean \pm s.e.m. for the no. of follicles or samples indicated in parentheses. Active follicles contained $>50 \mathrm{ng}$ oestradiol $/ \mathrm{ml}$ follicular fluid.

Within rows, values with different superscripts are significantly different at $P<0.05$.

\section{Plasma steroid binding}

All the ewes immunized against androstenedione-11-BSA produced detectable antiserum titres against androstenedione. The mean androstenedione antibody titres at the time of surgery were $1 / 110$ and $1 / 410$ for ewes in Groups 1 and 2 respectively. The specificity of the immune response was examined in the 4 animals from Group 1 and indicated significant binding of testosterone in $2 / 4$ ewes and of oestrone in 1/4 ewes (Martensz, 1977). No elevation in the binding of oestradiol-17 $\beta$ was detected (Martensz, 1977).

As shown in Table 6, the binding of androstenedione, oestrone and testosterone by plasma was significantly elevated in the immunized ewes; the binding of oestradiol was unchanged.

Table 6. The percentage binding of tritiated steroids $(15-20 \mathrm{pg})$ by a 1:5 dilution of jugular venous plasma from ewes immunized against androstenedione-11-BSA (immunized ewes) or BSA (control ewes)

\begin{tabular}{lcc}
\hline & $\begin{array}{c}\text { Immunized ewes } \\
(\mathrm{N}=4)\end{array}$ & $\begin{array}{c}\text { Control ewes } \\
(\mathrm{N}=4)\end{array}$ \\
\hline Oestrone & $91 \cdot 3 \pm 2 \cdot 0^{* * *}$ & $79 \cdot 3 \pm 0 \cdot 8$ \\
Oestradiol-17ß & $87 \cdot 1 \pm 0 \cdot 5$ & $89 \cdot 2 \pm 1 \cdot 8$ \\
Androstenedione & $99 \cdot 2 \pm 0 \cdot 1^{* * *}$ & $56 \cdot 2 \pm 2 \cdot 1$ \\
Testosterone & $98 \cdot 3 \pm 0 \cdot 5^{* * *}$ & $85 \cdot 6 \pm 1 \cdot 4$ \\
\hline
\end{tabular}

Values are mean \pm s.e.m.

Significantly different from control values, ${ }^{* * *} P<0.001$.

\section{Discussion}

All of the ewes immunized against androstenedione-11-BSA produced antisera with an increased capacity to bind tritiated androstenedione when tested in a dextran-coated charcoal radioassay or by equilibrium dialysis. The resultant decrease in metabolic clearance rate (Wickings, Becher \& Nieschlag, 1976) produced greatly elevated concentrations of biologically inactive andro- 
stenedione in the jugular venous plasma (Table 3). Plasma from some of the ewes immunized against androstenedione-11-BSA also contained antibodies capable of binding tritiated oestrone and testosterone, resulting in small increases in the peripheral concentrations of these steroids. No increase in the binding capacity of jugular venous plasma to tritiated oestradiol was seen in immunized ewes.

Ovulation rate and the number of visible surface follicles $>3 \mathrm{~mm}$ in diameter were increased in the immunized ewes although FSH concentration was lower than in control animals (Martensz \& Scaramuzzi, 1979). In the ewe, follicular development is thought to be a continuous process (Turnbull, Braden \& Mattner, 1977a) under the control of gonadotrophins. The elevated basal levels of LH in ewes immunized against androstenedione-11-BSA (Martensz \& Scaramuzzi, 1979) are associated with increased ovulation rate. Elevated LH levels have an antimitotic effect on the granulosa cells (McNatty \& Sawers, 1975) and might allow follicles capable of ovulating to remain viable for a longer period than normal (Turnbull, Land \& Scaramuzzi, 1977b). It has also been suggested that ovarian androgens increase the rate of follicular atresia (Louvet, Harman, Schreiber \& Ross, 1975). It is possible therefore that the binding of androgens by antibodies in follicular fluid and the vascular compartment of the androstenedione-immunized ewes reduced the rate of atresia in follicles $>3 \mathrm{~mm}$ diameter and so increased ovulation rate. The absence of any change in the number of visible follicles $<3 \mathrm{~mm}$ in diameter, despite the presence of altered FSH and LH levels, in the androstenedione-immunized sheep suggests that these earlier stages of follicular growth are proceeding normally and are less dependent on gonadotrophins.

Steroid secretion from the ovaries varied widely from animal to animal in the immunized ewes, and in general was characterized by increased net secretion (ovarian venous minus jugular venous concentrations) of androstenedione and of oestradiol during the preovulatory period. Since LH stimulates the secretion of both androstenedione and oestradiol (McCracken, Uno, Goding, Ichikawa \& Baird, 1969; Baird et al., 1976), and androstenedione is a major precursor of oestradiol in the sheep ovary (Rado, McCracken \& Baird, 1970), the increased concentrations of LH (Martensz \& Scaramuzzi, 1979), preovulatory oestradiol and androstenedione are in agreement with each other. These data also imply that circulating oestradiol has a reduced effectiveness on the negative feedback control of $\mathrm{LH}$.

The presence of elevated levels of progesterone in jugular venous plasma indicates that some alteration in the metabolism of progesterone occurred in the ewes immunized against androstenedione-11-BSA. Significant antibody titres to progesterone were also present in these animals (Martensz \& Scaramuzzi, 1979).

The concentrations of oestradiol- $17 \beta$ in follicular fluids from follicles $>5 \mathrm{~mm}$ diameter were apparently bimodal in distribution and the follicles were classified accordingly as inactive (oestradiol-17 , range $3 \cdot 0-48.8 \mathrm{ng} / \mathrm{ml} ; n=21$ ) and active (oestradiol- $17 \beta$, range $65 \cdot 2-292 \cdot 5$ $\mathrm{ng} / \mathrm{ml} ; n=22$ ). Elevated concentrations of oestradiol in follicular fluid are characteristic of preovulatory follicles (Sanyal, Berger, Thompson, Taymor \& Horne, 1974; McNatty, Hunter, McNeilly \& Sawers, 1975; Fowler, Chan, Walters, Edwards \& Steptoe, 1977) and it is possible that the follicles we have classified as active were indeed those follicles about to ovulate. It has been proposed that oestradiol in follicular fluid arises from androgens of thecal origin entering the granulosa cell where aromatization to oestrogens can occur under the influence of FSH (Dorrington, Moon \& Armstrong, 1975), but it is unclear which androgen (androstenedione or testosterone) serves as major precursor for aromatization. It seems likely that antibodies to androstenedione enter the follicle (Edwards, 1974) leading to increased concentrations of biologically inactive androstenedione in follicular fluid (Table 5) and hence reducing the availability of the steroid for conversion to oestrogens by granulosa cells. Since the concentration of oestradiol-17 $\beta$ was not reduced by immunization against androstenedione-11-BSA but follicular fluid levels of testosterone were lower in immunized ewes it is probable that most of the oestradiol-17 $\beta$ in follicular fluid of immunized ewes was derived from conversion of testosterone 
rather than androstenedione. Normally only follicles undergoing the final stages of preovulatory maturation would also have high concentrations of progesterone in their follicular fluid (McNatty et al., 1975; Fowler et al., 1977) and detectable LH receptors on their granulosa cells (R. S. Carson, J. K. Findlay, H. G. Burger \& A. O. Trounson, personal communication). Both active and inactive follicles in the ovaries of immunized ewes had high concentrations of progesterone in follicular fluid, presumably premature luteinization in response to the increased basal concentration of LH (Scaramuzzi et al., 1977).

We propose that immunization against androstenedione reduces the availability of biologically active androstenedione which effectively decreases the sensitivity of the hypothalamicpituitary unit to the feedback effect of oestradiol and results in increased LH release. The elevated LH levels then somehow act to increase the number of follicles available to ovulate. Alternatively, the binding of androgens to antibodies may reduce androgen-induced atresia, thereby increasing the availability of preovulatory follicles. Similar mechanisms may exist in breeds of sheep with high ovulation rates (e.g. Finnish Landrace) and the androstenedione to oestradiol ratio might be a correlate of the ovulation rate. However, at least two other factors can also modify ovulation rate, the rate of uptake of follicles into their rapid growth phase (Turnbull, Mattner, George \& Scaramuzzi, 1978) and the class (i.e. size) at which follicles mature and become capable of undergoing preovulatory changes and ovulation in response to LH (Turnbull et al., 1977a).

The technical help of W. G. Davidson, D. W. Davidson, I. G. Maddocks and I. Swanston is gratefully acknowledged. Androstenedione-11 $\alpha$-hemisuccinate was a gift from Dr G. Woods, Organon Laboratories, Newhouse, Lanarkshire, Scotland. The androstenedione-11 $\alpha$ hemisuccinyl-bovine serum albumin was prepared by Dr F. Rutherford, M.R.C. Radioimmunoassay Team, 2 Forrest Road, Edinburgh, EH1 2QW (Group 1), and Dr P. D. G. Dean, Department of Biochemistry, University of Liverpool, Cheshire, England (Group 2). Advice on statistical procedures was provided by $\mathrm{Dr} \mathrm{D}$. A. Griffiths and Mr J. B. Donnelly, CSIRO, Division of Mathematics and Statistics. P.V.L. was supported by the Nationaal Fonds voor Wetenschappelijk Onderzoek, Brussels, Belgium.

\section{References}

Baird, D.T. (1978) Synthesis and secretion of steroid hormones by the ovary in vivo. In The Ovary, 2nd edn, vol. 3, pp. 305-357. Eds S. Zuckerman \& B. J. Weir. Academic Press, New York.

Baird, D.T. \& Scaramuzzi, R.J. (1976) The source of ovarian oestradiol and androstenedione in the sheep during the luteal phase. Acta endocr., Copenh. 83, 402-409.

Baird, D.T., Burger, P.E., Heavon-Jones, G.D. \& Scaramuzzi, R.J. (1974) The site of secretion of androstenedione in non-pregnant women. $J$. Endocr. 63, 201-212.

Baird, D.T., Swanston, I. \& Scaramuzzi, R.J. (1976) Pulsatile release of $\mathbf{L H}$ and secretion of ovarian steroids in sheep during the luteal phase of the estrous cycle. Endocrinology 98, 1490-1496.

Corker, C.S. \& Davidson, D.W. (1978) A radioimmunoassay for testosterone in various biological fluids without chromatography. J. Steroid Biochem. 9, 373-374.

Dean, P.D.G., Exley, D. \& Johnson, M.W. (1971) Preparation of 17 $\beta$-oestradiol-6-(O-carboxymethyl) oxine-bovine serum albumen conjugate. Steroids 18 , $593-603$.
Dorrington, J.H., Moon, Y.S. \& Armstrong, D.T. (1975) Estradiol-17 $\beta$ biosynthesis in cultured granulosa cells from hypophysectomised immature rats, stimulation by follicle stimulating hormone. Endocrinology 97, $1328-1331$.

Edwards, R.G. (1974) Follicular fluid. J. Reprod. Fert. 37, 189-219.

Fowler, R.E., Chan, S.T.H., Walters, D.E., Edwards, R.G. \& Steptoe, P.C. (1977) Steroidogenesis in human follicles approaching ovulation as judged from assays of follicular fluid. $J$. Endocr. 72, 259271.

Louvet, J.P., Harman, S.M., Schreiber, J.R. \& Ross, G.T. (1975) Evidence for a role of androgens in follicular maturation. Endocrinology 97, 366-372.

Martensz, N.D. (1977) The experimental manipulation of gonadotrophins in non-pregnant sheep by immunization against steroid hormones. $\mathrm{PhD}$. thesis, University of Edinburgh.

Martensz, N.D. \& Scaramuzzi, R.J. (1979) The plasma concentrations of luteinizing hormone, folliclestimulating hormone and progesterone during the breeding season in ewes immunized against androstenedione or testosterone. J. Endocr. 81, 261-269. 
McCracken, J.A., Uno, A., Goding, J.R., Ichikawa, Y. \& Baird, D.T. (1969) The in vivo effects of sheep pituitary gonadotrophins on the secretion of steroids by the autotransplanted ovary of the ewe. J. Endocr. 45, 425-440.

McNatty, K.P. \& Sawers, R.S. (1975) Relationship between the endocrine environment within the Graafian follicle and the subsequent rate of progesterone secretion by human granulosa cells invitro. J. Endocr. 66, 391-400.

McNatty, K.P., Hunter, W.M., McNeilly, A.S. \& Sawers, R.S. (1975) Changes in the concentration of pituitary and steroid hormones in the follicular fluid of human Graafian follicles throughout the menstrual cycle. J. Endocr. 364, 555-571.

McNatty, K.P., Baird, D.T., Bolton, A., Chambers, P., Corker, C.S. \& McLean, H. (1976) Concentration of oestrogens and androgens in human ovarian venous plasma and follicular fluid throughout the menstrual cycle. J. Endocr. 71, 77-85.

Rado, A., McCracken, J.A. \& Baird, D.T. (1970) The formation of oestrogens by the autotransplanted ovary of the ewe perfused with $\mathrm{C}_{19}$ steroids. Acta Endocr., Copenh. 65, 244-260.

Rivarola, M.A., Forest, M.G. \& Migeon, C.J. (1968) Testosterone, androstenedione and dehydroepiandrosterone in plasma during pregnancy and at delivery: concentrations and protein binding. $J$. clin. Endocr. Metab. 28, 34-40.

Sanyal, M.K., Berger, M.J., Thompson, I.E., Taymor, M.L. \& Horne, H.W., Jr (1974) Development of Graafian follicles in adult human ovaries. I. Correlation of estrogen and progesterone concentration in antral fluid in growth of follicles. J. clin. Endocr. Metab. 38, 828-835.

Scaramuzzi, R.J. \& Land, R.B. (1978) Oestradiol levels in sheep plasma during the oestrous cycle. J. Reprod. Fert. 53, 167-171.
Scaramuzzi, R.J., Corker, C.S., Young, G. \& Baird, D.T. (1975) Production of antisera to steroid hormones. In Steroid Immunoassay, pp. 111-122. Eds E. H. D. Cameron, S. G. Hillier \& K. Griffiths. Alpha Omega Alpha Publications, Cardiff.

Scaramuzzi, R.J., Davidson, W.G., \& Van Look, P.F.A. (1977) Increasing the ovulation rate of sheep by active immunisation against an ovarian steroid androstenedione. Nature, Lond. 269, 817-818.

Swanston, I.A., McNatty, K.P. \& Baird, D.T. (1977) The concentration of prostaglandin- $\mathrm{F}_{2 \alpha}$ and steroids in the human corpus luteum. $J$. Endocr. 73, 115-122.

Turnbull, K.E., Braden, A.W.H. \& Mattner, P.E. (1977a) The pattern of follicular growth and atresia in the ovine ovary. Aust. J. biol. Sci. 30, 229-241.

Turnbull, K.E., Land, R.B. \& Scaramuzzi, R.J. (1977b) Patterns of growth of Graafian follicles in sheep and their relationship to ovulation rate. Theriogenology 8 , 172.

Turnbull, K.E., Mattner, P.E., George, J.M. \& Scaramuzzi, R.J. (1978) Relationship between patterns of ovarian follicle growth and ovulation rate in sheep. Aust. J. biol. Sci. 31, 649-655.

Van Look, P.F.A., Hunter, W.M., Corker, C.S. \& Baird, D.T. (1977) Failure of positive feedback in normal men and subjects with testicular feminization. Clin. Endocr. 7, 353-366.

Van Look, P.F.A., Clarke, I.J., Davidson, W.G. \& Scaramuzzi, R.J. (1978) Ovulation and lambing rates in ewes actively immunized against androstenedione. J. Reprod. Fert. 53, 129-130.

Wickings, E.J., Becher, A. \& Nieschlag, E. (1976) Testosterone metabolism in rabbits actively immunised with testosterone. Endocrinology 98, 1142-1146.

Received 15 February 1979 